\title{
Equity Market Liberalization and Corporate
}

\section{Governance* $^{*}$}

\author{
Kee-Hong Bae $\quad$ Vidhan K. Goyal ${ }^{\ddagger}$
}

August 26, 2008

\begin{abstract}
Equity market liberalization opens domestic stock markets to foreign investors. A common view of liberalization is that it improves risk sharing, increases investments and leads to higher growth. Yet the economic benefits of liberalization have not been as large as expected. There is strong evidence that foreign investors prefer to invest in relatively transparent firms and firms with better corporate governance. Such firms should benefit more from liberalization than other firms do. We examine these predictions using firm-level data around the time of the official equity market liberalization in Korea. The results show that firms that pay dividends, have more tangible assets, have lower leverage, and have better corporate governance grow faster and raise more external financing following equity market liberalization. Finally, we examine cumulative abnormal returns around the time of the liberalization in Korea and find that they are significantly higher for firms that have stronger governance. Stock price revaluations are more strongly linked to governance than to enhanced risk sharing.
\end{abstract}

JEL classification: D23, G21, G32, K42

Keywords: equity market liberalization, operating performance, cost of capital, corporate governance

${ }^{*}$ This research is supported by a grant from the Research Grants Council of the Hong Kong Special Administrative Region, China (Project No. HKUST6299/03H).

$\dagger$ Kee-Hong Bae, Department of Finance, Queen's School of Business, Queen's University, Kingston, Ontario, Canada, tel: 1-613-533-3275, kbae@business.queensu.ca

${ }^{\ddagger}$ Vidhan K. Goyal, Department of Finance, Hong Kong University of Science and Technology, Clear Water Bay, Kowloon, Hong Kong, tel: +852 2358-7678, goyal@ust.hk 


\section{Introduction}

Equity market liberalization opens a country's local stock markets to foreign investors. Theory suggests that liberalization reduces the cost of capital as foreign investors obtain diversification benefits from investing in emerging markets. Consistent with the reduction in the cost of equity, liberalization events are associated with substantial positive abnormal returns that are related to the diversification benefits provided by local stocks (Henry, 2000b; Chari and Henry, 2004). In addition, there is evidence that aggregate investment and growth increase following liberalization (Henry, 2000a; Bekaert et al., 2005).

Many economists have observed that despite the positive economic benefits, the effects of liberalization have not been as strong as might be expected (see, for example, Shleifer and Wolfenzon (2002), Henry and Lorentzen (2003), and Stulz (2005)). These studies offer two prominent explanations for why foreign investors seem slow to respond to the opening up of domestic markets.

First, many firms in emerging markets lack transparency, which causes severe adverse selection problems in these markets. Foreign investors are at a disadvantage relative to local investors when information asymmetries are large. Large, dividend-paying firms with large tangible assets are likely to have fewer asymmetric information problems than smaller firms. ${ }^{1}$ Thus, we expect relatively transparent firms to benefit more from the opening of markets to foreign investors.

Second, there is strong evidence that investor protection is weak in emerging markets. In environments with weak legal protection, controlling shareholders divert resources out of their firms in ways that outside minority investors can not easily monitor (Johnson et al., 2000b). ${ }^{2}$ Incentives to expropriate are significantly greater in firms affiliated with

\footnotetext{
${ }^{1}$ Kang and Stulz (1997) show that foreign investors in Japan prefer large, relatively more transparent firms that have low leverage.

${ }^{2}$ Johnson et al. (2000b) show that profit diversion can take many forms. These include a variety of self dealing transactions such as asset sales, transfer pricing contracts, excessive compensation, loan guarantees and financial transactions such as dilutive share issues, minority freezeouts, and insider trading. Legal protection of minority shareholders and creditors is significantly associated with financial development across countries (La Porta et al., 1997). In addition, during times of crisis, corporate governance measures affect operating performance and stock market valuations (see, for example, Mitton, 2002; Lem-
} 
business groups, where the gap between ownership and control is wide (Claessens et al., 2000; Friedman et al., 2003). ${ }^{3}$ Investors are likely to be reluctant to invest in stocks when they suspect that there are significant risks from expropriation. Surveys have revealed that foreign investors have strong preferences for investing in better governed firms in emerging markets (Co., 2002). ${ }^{4}$ Thus, we expect that better governed firms will benefit more from equity market liberalization than will poorly governed firms.

Most previous studies use country-wide data or industry data rather than firm-specific data to study the effects of equity market liberalization. ${ }^{5}$ As a consequence, we know little about whether liberalization affects all firms in an economy or if it helps some firms more than others. Do more transparent and better governed firms benefit more from liberalization than do less transparent and poorly governed firms? In particular, do transparent and better governed firms raise more external financing, invest more and grow faster than less transparent and poorly governed firms after liberalization? Are abnormal returns around equity market liberalization higher for firms that are more transparent and better governed?

We seek to answer these questions and provide new findings on the effects of equity market liberalization using disaggregated data from Korea. Korea officially liberalized its equity market in January 1992. The Korean economy is certainly interesting for many reasons, it is also the only emerging market economy with readily available ownership data from the late 1980s and early 1990s. ${ }^{6}$ Furthermore, our evidence from Korea on how

mon and Lins, 2003). Johnson et al. (2000a) showed that countries with strong legal protection were less affected by crises. Joh (2003) showed that even before a crisis, there is a negative relation between corporate governance and performance.

${ }^{3}$ For empirical evidence on business groups and expropriation of minority shareholders, see La Porta et al. (1999), Bertrand et al. (2002), Bae et al. (2002), and Joh (2003).

${ }^{4}$ In the Global Investor Opinion Survey conducted by McKinsey\&Co. in 2002, investors stated that they place corporate governance on par with financial indicators when evaluating investment decisions. Strikingly, $63 \%$ of the respondents in the survey avoided investing in companies with poor governance. A U.S. investment manager of a US $\$ 20$ billion private equity fund commented, "[O]ur investment group would never approve an investment in a company with bad governance."

${ }^{5}$ The exceptions are Mitton (2006) and Chari and Henry (2007).

${ }^{6}$ The governance data for other emerging economies during the late 1980s and early 1990s is not readily available. In some emerging markets, the data were not even disclosed during the periods when liberalization occurred. 
governance affects liberalization can be easily generalized to other emerging markets that have gone through similar market liberalization. Many aspects of Korean firms resemble those of other emerging economies.

The tests exploit two governance features of Korean firms. First, many Korean firms belong to business groups known as chaebols, accounting for a significant part of the country's economy. ${ }^{7}$ Previous studies show that corporate governance is relatively worse among chaebol-affiliated firms. ${ }^{8}$ Independent firms (i.e., those not affiliated with a chaebol), by contrast, are relatively more transparent and have fewer agency problems. Second, a greater ownership of cash flow rights by the largest shareholder aligns the interests of controlling shareholders with those of minority shareholders. In summary, firms unaffiliated with chaebols (independent firms) and firms in which the largest shareholder owns a substantial stake are likely to be better governed.

The empirical analysis proceeds in two steps. First, we examine external financing, investments, and sales growth rates before and after the equity market liberalization. In particular, we examine variation across firms classified by size, dividend paying status, tangibility of assets, chaebol affiliation, and ownership concentration. The objective is to examine if firms that are large, pay dividend, have more tangible assets, are unaffiliated with chaebols and have greater concentration of ownership derive larger economic benefits from liberalization compared with other firms. Second, we estimate cumulative abnormal returns in the month of the liberalization and then relate these abnormal returns to firm characteristics and governance variables after controlling for other determinants of liberalization-induced stock revaluations.

Our findings suggest that, in Korea, dividend-paying firms and firms with more tangible assets experienced relatively faster growth rates in the period following liberalization. Other firms experienced declining growth rates. In addition, the findings show that firms not affiliated with chaebols (the independent firms) and firms with concentrated ownership

\footnotetext{
${ }^{7}$ According to Chung and Yang (1992), the largest 30 chaebols produced $35.4 \%$ of total output and $16.3 \%$ of GDP in 1989 .

${ }^{8}$ See Bae et al. (2002) and Baek et al. (2004) for a detailed discussion of Korean business groups and their governance structures.
} 
grew faster relative to other firms following liberalizations. These results are consistent with our key predictions that corporate governance and transparency determine which firms benefit from the opening up of domestic markets to foreign investors.

In addition to examining growth, we examine if firms invest more and raise more external financing after market liberalization. While the investment results are weak, we find strong patterns in external financing that are consistent with transparency and governance playing a prominent role in determining who benefits from liberalization. Dividend-paying firms and independent non-chaebol firms raise more external financing after liberalization. Independent firms issue relatively more debt while dividend-paying firms issue relatively more equity following liberalization.

In the second step, we examine the cross-sectional variation in abnormal returns in the month of liberalization. We determine if the revaluation effects are related to the two governance measures, the independent firm indicator and the concentrated ownership firm indicator. Consistent with our hypothesis that governance matters in determining who benefits from liberalization, the cumulative abnormal returns in the liberalization month are significantly higher for firms that have strong governance. More specifically, we find that the abnormal returns are higher for firms unaffiliated with chaebols and for firms with more concentrated ownership. To discriminate between the governance view and the risksharing view, we control for the differences in covariances between firm returns and the local market and firm returns and the world market (DIFCOV). Consistent with Chari and Henry (2004), the results show that DIFCOV is positively related to abnormal returns as the risk-sharing hypothesis predicts. However, the governance effects on abnormal returns are substantially larger compared to those of DIFCOV on abnormal returns. In these tests, we control for stock turnover, firm size, leverage and cash flow.

Other results show that abnormal returns are larger for small firms. The finding that small firms benefit more from liberalization is consistent with a greater relaxation of financing constraints for small firms. When firm size is interacted with changes in external finance in the regressions, the results indicate that stock revaluations are significantly 
larger for small firms that subsequently increased their external financing.

In summary, our results show that firms with strong governance structures benefit most from liberalization. Policymakers should therefore focus more on improving governance structures before liberalizing their equity markets. Another way of interpreting the results is that companies benefit from improving their corporate governance mechanisms prior to market liberalization. It is useful for countries that are considering liberalizing their equity markets to study the experience of other countries. ${ }^{9}$.

The paper is organized as follows. Section 2 explains the hypotheses about how firms would respond to equity market liberalization. Section 3 describes the data and variables and dates the liberalization event in Korea. Section 4 provides statistics on changes surrounding liberalization event in Korea. Section 5 presents results from regressions of growth, investment, and external financing. Section 6 presents results from regressions of cumulative returns on governance variables and changes in investment and financing around the time of the liberalization in Korea. Section 7 concludes the paper.

\section{Liberalization and corporate governance}

Explicit barriers to investing in Korean equity markets fell in January 1992 when a formal regulatory change officially allowed foreign investors to invest in Korean equities. The Chronology of Important Economic, Financial, and Political Events in Emerging Markets by Bekaert and Harvey (2005) notes that the official liberalization in Korea meant that foreign investors could own up to $10 \%$ of the capitalization of a company while no individual foreign investor could own more than 3\%. ${ }^{10}$ These limits were subsequently revised upwards in subsequent years and finally abolished after the Asian financial crisis.

\footnotetext{
${ }^{9}$ See the discussion in Dharwadkar et al. (2000), Gedajlovic and Shapiro (1998), Burkart et al. (1997) and Slovin and Sushka (1997)

${ }^{10} \mathrm{http}: / /$ www.duke.edu/ charvey/chronology.htm. In addition, IFC and a number of previous papers consider January 1992 as the time of the equity market liberalization for Korea (see, for example Kim and Singal, 2000; Chari and Henry, 2004; Bekaert et al., 2005). Recognizing that liberalization is a gradual event and occurs in stages, Bekaert et al. (2002) date the capital market integration using structural break tests. In their tests, the Wald statistic was above its critical value in January 1992 for Korea.
} 
Theory predicts that when a country opens its markets to foreign investors, portfolio equity flows into that country would be large because foreign investors diversify portfolios internationally to share risks. However, a continuing puzzle in the literature is that capital flows into markets that have liberalized have not been as large as predicted by theory (Lucas, 1990). In recent papers, Henry and Lorentzen (2003) and Stulz (2005) suggest that corporate governance and information problems affecting firms in emerging markets perhaps explain why a significant home bias still exists and equity flows into emerging markets are small compared to what the theory predicts.

We employ firm-level data for Korean firms around the time of the market liberalization in Korea in 1992 as an experiment to examine if firms that are expected to have less severe information and governance problems indeed derive relatively more benefits from liberalization. Our approach to examining a panel of firms within a country has both benefits and costs. The benefit of examining firm-level performance surrounding a market-wide event is that the event itself is exogenous to any particular firm. Endogeneity problems are not great concern in this paper. The cost is that by treating equity market liberalization as a country-wide event, we are placing more than usual emphasis on the identification of the event. This does not seem to be a big issue in this case since the official liberalization date is clearly established.

Corporate finance theories predict that greater ownership by controlling shareholders (insiders) can mitigate the adverse impact of agency problems. If insiders do not own much of the cash flow rights in the firm, they will have large incentives to divert resources or extract private benefits. As Kho et al. (2006) argue, for private benefits to affect investment decisions of foreign investors, it must be that these investors have differences of opinion about the anticipated consumption of private benefits by insiders. If local investors have more precise information, foreign investors will be reluctant to invest in these firms since they would be at an information disadvantage. Thus, we expect firms where ownership is more concentrated to have better governance. If foreign investors invest in better governed firms, then firms with concentrated ownership should benefit 
more from liberalization. The one constraint that Kho et al. identify is that there is not a large free float for foreign investors to buy into in firms with concentrated ownership. They find evidence that shows that foreign investors increase their ownership stakes as ownership gets dispersed. This liquidity consideration places an important constraint on the benefits that firms with concentrated ownership derive from the liberalization of equity markets.

On the other hand, firms in which controlling shareholders hold more control rights than cash flow rights have worse governance. In these firms, controlling shareholders have strong incentives to expropriate resources from minority shareholders. Consistent with this argument, Leuz et al. (2006) show that US investors invest less in firms in which the controlling shareholder holds more control rights in countries with poor disclosure. The divergence between control rights and cash flow rights is severe in firms affiliated with business groups. In Korea, many firms are affiliated with business groups known as chaebols. We focus our analysis on firms that are independent (i.e., unaffiliated with a chaebol) and those that are affiliated with chaebols. The firms affiliated with chaebols are identified from announcements of member firms in the top 30 chaebols made annually by the Korea Fair Trade Commission. There is quite a bit of evidence that firms affiliated with business groups have lower transparency and weaker corporate governance. Diversified business groups in emerging markets are relatively more opaque. The resulting information asymmetry allows controlling shareholders to expropriate minority shareholders (Lins and Servaes, 2002; Lins, 2003). More directly, Bae and Jeong (2002) show that the accounting information from Korean business groups is less transparent compared to that from unaffiliated firms. There is also strong evidence that controlling shareholders in Korean groups engage in transactions that expropriate minority investors. Bae et al. (2002) provide striking evidence suggesting that Korean business groups divert resources through acquisitions transactions. Similarly, Chang (2002) provides evidence on how controlling shareholders in chaebols use private information to increase their stakes in more profitable firms and transfer profits to other affiliates through intra-group trades. 
In summary, the evidence on Korean firms suggest that corporate governance problems are more severe for chaebol-affiliated firms than they are for independent firms.

If investors are more likely to invest in better governed, relatively transparent firms, then sales growth, investment and external financing will increase relatively more for these firms after liberalizations. If investors anticipate that better governed firms will benefit more from liberalization, then the stock revaluation in the liberalization month would be larger for these firms. At the country level, there is evidence of higher growth following liberalization. Bekaert et al. (2005) show that liberalization leads to an increase in a country's annual economic growth. However, a recent survey by Kose et al. (2006) concludes that the evidence on the impact of financial globalization on firm growth is at best mixed. We do not know if the growth effects are uniformly higher for all firms or if some firms benefit more. What determines the variation in growth rate effects after liberalization? Based on the discussion above, we predict that growth effects would be larger for transparent and better governed firms.

There is also evidence presented by Henry (2000b) and Chari and Henry (2004) that liberalization is accompanied by large stock revaluation. Bekaert and Harvey (2000) and Kim and Singal (2000) argue that the rise in stock prices around liberalization is consistent with a reduction in the cost of equity. However, if foreign investors prefer transparent and better governed firms, the revaluation will be larger for the stocks that investors prefer. Henry (2000a) shows that liberalization is associated with increases in private investment at the country level. Chari and Henry (2007) show that future investments are correlated with expectations of changes in a firm's cash flows. We expect that firms that have lower information asymmetry and better governance invest more and raise more external finance with liberalization. 


\section{Data Description}

We obtain the accounting and ownership data from the Listed Company Database of the Korean Listed Companies Association. Our analysis focuses on the period from 19881995 spanning the equity liberalization date. The balance sheet and income statements of Korean firms have consistent formats throughout this period. There was a change in the reporting of cash flow statements, however. Prior to 1994, firms reported statements of change in working capital. After 1994, firms reported statement of cash flows. However, the key items in the before and after 1994 statements, i.e., investments, issuances and retirements of debt and equity are consistently reported.

To be included in the sample, we require firms to report positive sales and assets. We exclude firms that are in transport and regulated industries. ${ }^{11}$ We require that sample firms have stock returns in each month during the period surrounding liberalization in the Korea Securities Research Institute (KSRI) files. Local currency values are converted to real values using the CPI deflator. The CPI index is obtained from ECONSTATS Global Data maintained by the International Monetary Fund. ${ }^{12}$ By applying these criteria, we end up with a sample of 300 firms.

\subsection{Firm and ownership characteristics}

Table 1 summarizes the data. Panel A provides summary statistics on firm and ownership characteristics. Panel B summarizes the cumulative abnormal returns around liberalization, the differences in covariances and stock turnover. ${ }^{13}$

We measure Sales Growth as the change in real sales divided by lagged sales. In the year prior to liberalization, real sales increased on average by $8.7 \%$ (the median is $5.5 \%)$. Investment is defined as the ratio of capital expenditure to lagged assets. We

\footnotetext{
${ }^{11}$ Kang and Stulz (1997) show that foreign investors dramatically underweight regulated industries. This exclusion does not materially affect our results.

${ }^{12}$ International Financial Statistics and EconStats (http://www .econstats .com).

${ }^{13}$ The ratios from the financial statement data are winsorized in the tails of their distributions at $1 \%$. This serves to remove outliers and the most extremely mis-recorded data.
} 
also examine investments in both fixed assets and working capital, defined as Inv $\Delta W C$. Firms invested roughly $8 \%$ of their total assets in capital expenditure each year. Working capital investments added less than $1 \%$ to the total investment in both fixed assets and working capital. External Finance is defined as the sum of net debt issues and net equity issues. This estimate is obtained from financing cash flow information on the statements of changes in cash flows. We define Net Debt Issues as the difference between debt issuances and debt repurchases. Similarly, Net Equity Issue is defined as equity issues minus equity repurchases. The sample firms raised about 11 percent of their assets from external capital markets. A large part of this was in the form of debt. Most Korean firms appear to have been inactive in the equity market since both the $25^{\text {th }}$ percentile and median are zero. The average net equity issue/assets ratio is 0.01 .

The average Market Capitalization is 86.9 billion won (or US\$86.9 million at the exchange rate of 1000 won per 1 US\$). The median is much smaller at 29.1 billion won, suggesting the presence of many large firms in the sample. The average operating cash flow to total assets ratio is $5.9 \%$. Leverage, measured as the ratio of total debt to book assets, is about 0.43. Tangibility defined as the ratio of fixed assets to total assets is 0.32 on average (the median is 0.31 ). The Dividend-paying firm indicator variable takes a value of one if the firm pays a dividend and it is zero otherwise. About $82 \%$ of the sample firms paid dividends. About $29 \%$ of the firms are affiliated with a business group (Chaebol dummy=1 for affiliated firms). Ownership in Korean firms is highly concentrated with the largest shareholder holding $23 \%$ equity in the firm. The median is also $23 \%$.

\subsection{CARs, difference in covariance and stock turnover}

We estimate mean-adjusted abnormal returns (CAR) for each firm as the difference between the return in the liberalization month and the average, pre-liberalization, monthly return over the previous year ending 12 months before the implementation date. To check if the results are robust to the estimation procedure, we also estimate abnormal returns using a market model with an estimation period that starts in month t-48 and ends at t-13. 
While the market model requires a long estimation period with a consequent reduction in the sample, the results from the two methods are qualitatively identical. We also examine robustness to the choice of the event window by also computing CARs over two months (the liberalization month and the month after). Again, we find virtually similar results.

Panel B of Table 1 summarizes the cumulative abnormal returns (CARs) in the liberalization month, the differences in covariances and stock turnover. The average CAR in the liberalization month is $24 \%$ (the median is $21 \%$ ). These results are consistent with Henry (2000b) who also provides evidence of significant revaluations of equities around liberalization events. In unreported tests, we used a two month window (the month of the liberalization and the month after) and found the mean and median CARs to be 21.4 percent and 17.5 percent, respectively. These CARs are economically large and significantly different from zero. ${ }^{14}$ Thus, stock market liberalization is associated with substantial stock revaluation in Korean.

We also estimate the difference in the covariance of firm returns with the local market and firm returns with the world market (DIFCOV). Chari and Henry (2004) show that part of the stock price revaluation on the liberalization date reflects diversification benefits, which are driven by changes in the level of systematic risk. Thus, we expect that a higher DIFCOV should lead to higher abnormal returns. We follow Chari and Henry (2004) to estimate the DIFCOV. The local index is the KOSPI, a value-weighted index for the Korean stock market. The average difference in covariance is 0.0028 and the median is 0.0030. Finally, as a measure of liquidity, we examine the average turnover for a stock in the period $t=-23$ to $t=-12$. The mean is 0.0024 and the median is 0.0014 .

\section{Changes around liberalization}

Table 2 presents median pre- and post-liberalization values of sales growth, investments, and external financing. We present these statistics for all firms and for firms

\footnotetext{
${ }^{14}$ Chari and Henry (2004) examine a much smaller sample and find even higher CARs (55\%) over the eight months of the liberalization window.
} 
classes by affiliation with business groups (group-affiliated and independent firms), by ownership concentration (less concentrated and more-concentrated), by firm size (small and large firms) and by dividend-paying status (non-dividend paying and dividend paying). The pre-liberalization period is defined as 1988-1991 and the post-liberalization period is defined as 1992-1995.

Columns 1 and 2 present the results for all firms. The median sales growth is almost identical during the two periods. Capital expenditure fell but working capital investments increased substantially. Thus, investments in both fixed assets and working capital rose significantly. Firms raised slightly less external finance overall. Much of the external financing after liberalization was in the form of debt financing, which declined a little after liberalization. Median firms did not issue equity either before or after liberalization.

An examination of group-affiliated and independent firms (in columns 3 to 6) reveals significant differences in sales growth across these two groups during the liberalization period. Sales growth fell for chaebol firms around liberalization (from 9.5\% to 7.6\%) but increased for independent firms (from 2.5\% to 3.1\%). Similarly, we find that investments in both fixed assets and working capital declined for group-affiliated firms after liberalization but increased for independent firms. External finance fell more for chaebol firms and not as much for independent firms. Net debt issues fell for chaebols but increased for independent firms. Median net equity issues were zero for both classes of firms.

We find similar differences between firms with different levels of ownership concentration. For firms with less concentrated ownership, sales growth declined after liberalization. But for firms with more concentrated ownership, sales growth increased substantially. ${ }^{15}$ Investments in fixed assets and working capital seem to have increased for both types of firms. The firms also increased their external financing, which was mostly in the form of net debt issuance.

We further examine firm classes based on size and dividend dummy in columns 11

\footnotetext{
${ }^{15}$ Bekaert et al. (2001) provide some indirect evidence on the effect of corporate governance on growth following liberalizations. They show that better governance as measured using the enforcement of insider trading laws (Bhattacharya and Daouk, 2002) positively affects growth.
} 
to 18. These classifications are done based on assets and dividend status in 1991. Sales growth increased for small firms but fell for large firms. Although previous evidence suggests that foreign investors have a preference for larger firms, financing constraints are more severely binding for smaller firms. These firms therefore experience a larger increase in growth after liberalization. Large firms are usually unconstrained prior to liberalization and often have directed access to external financing (Laeven, 2003). Consistent with this argument, we find an increase in net debt issues by small firms after liberalization. Large firms issued relatively less debt after liberalization.

Finally, we examine dividend-paying versus non-dividend-paying firms. Sales growth increased for dividend paying firms and fell for for non-dividend-paying firms. Financing constraints reduced for non-dividend-paying firms as can be seen in a significant increase in debt issues by non-dividend-paying firms. Dividend payers experienced a small decline in debt issues.

\section{Growth, investment and financing: Results}

Table 3 presents results from OLS regressions of sales growth on liberalization indicators, and interaction terms. These regressions control for firm size, dividend-paying status, tangibility, group affiliation, and ownership. The standard errors are corrected for clustering at the firm level.

The coefficient estimate on firm size is positive and statistically significant at the $1 \%$ level. This is consistent with the results in the previous section that show that large firms

grew relatively faster before liberalization. Large firms presumably have better access to credit and are less financially constrained prior to liberalizations. The coefficient on the dividend dummy and tangibility are both negative but not statistically significant in most specifications. The negative and significant coefficient on concentrated ownership suggests that these firms also experienced slower growth rates pre-liberalization.

The indicator variable, Liberalize, takes a value of one for the years from 1992 to 1995 
and a value of zero for years from 1988 to 1991. Although we base our main analysis on this definition of pre- and post- liberalization windows, the results are not sensitive to shortening the window and excluding the year of the liberalization.

The negative coefficient on the interaction term between liberalization and firm size suggests that liberalization increased sales growth for small firms and reduced growth for large firms. The coefficient is not statistically significant, however. The estimated coefficient on the interaction between liberalization and the dividend dummy is positive and statistically significant at the 10 percent level. Thus, firms paying dividends grew relatively faster after liberalization compared to non-dividend-paying firms. Firms with more tangible assets grew faster. The coefficients on the interaction term between the liberalization and independent firm indicator is positive. This estimate implies that unaffiliated firms had relatively higher growth in sales compared to chaebol firms after liberalization. The positive and significant coefficient on the interaction between liberalization and concentrated ownership implies that growth was relatively higher for firms with more concentrated ownership compared to firms with less concentrated ownership.

Table 4 presents results from investment regressions. The dependent variables is the ratio of capital expenditure to lagged assets. The independent variables include sales growth, cash flows, the independent firm indicator, the concentrated ownership indicator, firm size, dividend dummy, tangibility, the liberalization indicator and its interaction terms. As before, the t-statistics are corrected for clustering at the firm level. As expected, investment is positively related to growth and cash flows. Independent firms invest less in fixed assets before liberalization. Firms with more tangible assets invest more in fixed assets. We find that investments increased for larger firms after liberalization. Other interaction terms are not statistically significant.

In Table 5, we find that external financing increased after liberalization for dividendpaying firms. The coefficient estimate on the interaction term between liberalization and the dividend dummy is positive and significant, as is the coefficient estimate on the interaction between liberalization and the independent firm indicator. These results 
suggest that unaffiliated firms and dividend-paying firms raised significantly more external finance relative to non-chaebols. The coefficient estimate on the interaction term between liberalization and the concentrated ownership indicator is positive but statistically not significant at conventional levels.

Table 6 presents a specification similar to that of the previous table but examines changes in net debt issues. Firm size and asset tangibility lead to greater debt issuance. Profitability and growth are insignificant. Lagged leverage is positively related to net debt issuance. The only significant interaction term is between liberalization and independent firms. This suggests that independent firms raised more debt financing after liberalization compared to chaebol-affiliated firms.

Table 7 presents results from OLS regressions of net equity issues on firm size, asset tangibility, profitability, sales growth, and leverage as control variables. The key variables of interest are the liberalization indicator, the governance variables, and various interaction terms. Consistent with results reported above, dividend-paying firms issued substantially more equity compared to non-dividend-paying firms.

\section{Liberalization returns, transparency, and governance: Results}

We now examine if abnormal returns around equity market liberalizations are higher for firms that are better governed. If stock market liberalization benefits firms with better corporate governance, then we would expect the liberalization returns to be smaller for chaebol-affiliated firms and larger for firms with more concentrated ownership. To examine the effect of governance on liberalization returns, we regress the cumulative abnormal returns on the independent firm indicator and ownership concentration as follows. In addition, we include DIFCOV to control for risk-sharing benefits that affect cumulative abnormal returns. The other control variables include firm size, stock turnover, cash flow and leverage. Stock turnover is included to control for liquidity, which might change 
significantly following stock market liberalization. We control for cash flow because profitable stocks may experience greater increases in stock values. We control for leverage since more levered stocks are more risky.

$$
\begin{aligned}
\text { CAR }_{j}= & \alpha+\beta_{1} \text { DIFCOV }_{j}+\beta_{2} \text { Independent }_{j} \\
& +\beta_{3} \text { BigOwner }_{j}+\beta_{4} \text { Turnover }_{j}+\beta_{5} \text { Profit }_{j}+\beta_{6} \text { MktCap }_{j} \\
& +\beta_{4} \text { Leverage }_{j}++\varepsilon_{j} .
\end{aligned}
$$

The standard assumptions required for this estimation are violated because all firms have the same liberalization date. The estimation procedure therefore adjusts the variancecovariance matrix used to calculate the standard errors to account for clustering and for heteroscedasticity across firms.

Table 8 presents the regression results. The dependent variable is the mean adjusted abnormal-return for the liberalization month. Column 1 reports results from regressions that test for the effect of risk sharing. The key variable on the right-hand side is DIFCOV. The control variables are stock turnover, cash flow profitability, leverage and the log of market capitalization. If improved risk sharing reduces systematic risk, then we would expect stock revaluations to be higher when the segmentation between domestic and global markets is greater. Consistent with the prediction of the risk-sharing hypothesis, the result shows that DIFCOV is positively related to abnormal returns. Chari and Henry (2004) also find a positive coefficient on the DIFCOV variable in CAR regressions.

Column 2 includes the independent firm indicator to the baseline regression reported in Column 1. The estimated coefficient on the independent firm indicator is positive and highly significant, suggesting that unaffiliated firms have much higher increases in market valuation compared to chaebol firms. In Column 3, we include the ownership indicator and find a significant positive coefficient, suggesting that firms with greater share ownership by the largest shareholder experienced more positive abnormal returns. In Column 3, we 
include both the independent firm indicator and the concentrated ownership indicator. Both coefficients are positive and statistically significant.

The coefficient on stock turnover is negative, suggesting that the liberalization was of greater benefit to firms that had lower liquidity. Liberalization is expected to improve liquidity because of larger capital inflows and these benefits would be larger for less liquid stocks. The coefficient on profitability is positive, suggesting that profitable firms benefited more from liberalization than did less profitable firms. If profitable firms have access to better projects and liberalization reduces the cost of external financing, then we will expect more profitable firms to have higher CARs around the time of the market liberalization. The coefficient on firm size is significant and negative. This is consistent with smaller firms benefiting more from liberalization. The reduction in the cost of capital and lower external financing costs are significantly more beneficial to smaller firms compared to larger firms. The coefficient on leverage is positive but not significant.

In summary, the results suggest that corporate governance has a significant effect on stock price revaluation. There is also some evidence of increased risk sharing. Firms with poor corporate governance benefit less from market liberalization. Our findings that better governed firms benefit more from liberalization suggest an important policy implication. The necessary condition of fully realizing the benefits of market liberalization is to strengthen corporate governance systems. Chaebol firms are said to suffer from more serious agency problems (Bae et al., 2002). Thus, the evidence is consistent with the idea that poorly governed firms benefit less from liberalization. The governance channel though which liberalization affects local markets is as important as or perhaps more important than the risk-sharing channel.

In Table 9, we augment the liberalization return regressions by including changes in growth, investment and external finance. Only change in investment has a significant positive relation to abnormal returns. This positive association between investment increases and abnormal returns is consistent with findings by Chari and Henry (2007). Abnormal returns are unrelated to changes in sales growth and changes in external finance. In columns 
4 and 5, we include additional interaction terms between external finance and firm size.

When small firms are able to raise external finance, the stock price revaluations are likely to be larger since small firms are expected to be relatively more financially constrained. The negative coefficient on change in external finance and firm size is consistent with our prediction that wealth benefits for shareholders are larger when financing constraints relax for small firms, enabling them to raise larger quantities of financing subsequently. When we decompose external finance into net debt issuance and net equity issuance, we find that again abnormal returns are higher when small firms raise more debt and equity financing. The coefficient estimates on other control variables are similar.

\section{Conclusions}

The economic benefits of equity market liberalizations have not been as large as theory predicts. In this paper, we examine if firms that are relatively more transparent and better governed benefit more from liberalization compared to other firms. This prediction is based on the argument that foreign investors are reluctant to invest in firms that have significant information and governance problems. The data surrounding Korean market liberalization in January 1992 is used to test the predictions. The results support the key predictions. Dividend-paying firms and firms with tangible assets are expected to be more transparent. These firms grew faster after liberalization and raised more financing afterwards. In addition, we find that governance plays a major role in determining how firms respond to liberalization. Firms that are unaffiliated with business groups are expected to have better governance. These firms exhibit faster growth and higher levels of external financing after liberalization compared to chaebol-affiliated firms.

In addition to firm characteristics, we also examine stock price revaluations around the liberalization event. Abnormal returns around liberalization are higher for independent firms and firms that have more concentrated ownership. We also find that liberalization returns are positively related to the differences in covariance and are negatively related 
to stock turnover.

Overall, results imply that firms that are more transparent and have better corporate governance benefit more from the opening of stock markets. Poorly governed firms benefit less. This is consistent with foreign investors often revealing their preferences for better governed firms. The results show that risk sharing is important too, however the effects of risk sharing are not as large as those of governance. 


\section{References}

Bae, Kee-Hong, and S.W. Jeong, 2002, The value-relevance of accounting information, ownership structure, and business group affiliation: Evidence from korean business groups, working Paper.

Bae, Kee-Hong, Jun-Koo Kang, and J.M. Kim, 2002, Tunneling or value added? evidence from mergers by korean business groups, Journal of Finance 62, 2695-2740.

Baek, Jae-Sung, Jun-Koo Kang, and Kyung Suh Park, 2004, Corporate governance and firm value: Evidence from the korean financial crisis, Journal of Financial Economics $71,265-313$.

Bekaert, G., and C.R. Harvey, 2000, Foreign speculators and emerging equity markets, Journal of Finance 55, 565-613.

Bekaert, G., and C.R. Harvey, 2005, Chronology of important economic, financial and political events in emerging markets, http://www.duke.edu/ ${ }^{\sim}$ charvey/chronology.htm.

Bekaert, G., C.R. Harvey, and R.L. Lumsdaine, 2002, Dating the integration of world equity markets, Journal of Financial Economics 65, 203-247.

Bekaert, G., C.R. Harvey, and C. Lundblad, 2001, Emerging equity markets and economic development, Journal ofDevelopment Economics 66, 465-504.

Bekaert, G., C.R. Harvey, and C. Lundblad, 2005, Does financial liberalization spur economic growth, Journal of Financial Economics 77, 3-55.

Bertrand, M., P. Mehta, and S. Mullainathan, 2002, Ferreting out tunneling: An application to indian business groups, Quarterly Journal of Economics 117, 121-148.

Bhattacharya, U., and H. Daouk, 2002, The world price of insider trading, Journal of Finance 57, 75-108.

Burkart, Mike, Denis Gromb, and Fausto Panunzi, 1997, Large shareholders, monitoring, and the value of the firm, Quarterly Journal of Economics 112, 693-728.

Chang, S. J., 2002, Ownership structure, expropriation, and performance of groupaffiliated companies in korea, Academy of Management Journal, Forthcoming .

Chari, A., and P.B. Henry, 2004, Risk sharing and asset prices: Evidence from a natural experiment, Journal of Finance 59, 1295-1324.

Chari, A., and P.B. Henry, 2007, Firm-specific information and the efficiency of investment, Journal of Financial Economics Forthcoming.

Chung, B, and Y. Yang, 1992, Economic analysis of the korean chaebol sector. 
Claessens, S., S. Djankov, and L. Lang, 2000, The separation of ownership and control in east asian corporations, Journal of Financial Economics 58, 81-112.

Co., McKinsey \&, 2002, Global investor opinion survey: Key findings, McKinseyEGCo. . URL: http://www.mckinsey.com/clientservice/organizationleadership/service

Dharwadkar, R., G. George, and P. Brandes, 2000, Privatization in emerging economies: An agency theory perspective, Academy of Management Review 25, 650-689.

Friedman, E., S. Johnson, and T. Mitton, 2003, Propping and tunneling, Journal of Comparative Economics 31, 732-750.

Gedajlovic, E.R., and D.M. Shapiro, 1998, Management and ownership effects: Evidence from five countries, Strategic Management Journal 19, 533-553.

Henry, P.B., 2000a, Do stock market liberalizations cause investment booms?, Journal of Financial Economics 58, 301-334.

Henry, P.B., 2000b, Stock market liberalization, economic reform, and emerging market equity prices, Journal of Finance 55, 529-564.

Henry, P.B., and P.L. Lorentzen, 2003, Domestic capital market reform and access to global finance: Making markets work, in M. Pomerleano, R.E. Litan, and V. Sundararajan, (eds.) The future of domestic capital markets in developing countries (Brookings Institution Press).

Joh, S.W., 2003, Corporate governance and firm profitability: Evidence from korea before the economic crisis, Journal of Financial Economics 68, 287-322.

Johnson, S., P. Boone, A. Breach, and E. Friedman, 2000a, Corporate governance in the asian financial crisis, Journal of Financial Economics 58, 141-186.

Johnson, S., R. La Porta, F. Lopez-de Silanes, and A. Shleifer, 2000b, Tunnelling, American Economic Review 90, 22-27.

Kang, J.-K., and R. Stulz, 1997, Why is there a home bias? an analysis of foreign portfolio equity ownership in japan, Journal of Financial Economics 46, 3-28.

Kho, B-.C., R.M. Stulz, and F.E. Warnock, 2006, Financial globalisation, governance and the evolution of the home bias, bIS Working Paper \#220, Bank for International Settlements.

Kim, E.H., and V. Singal, 2000, Does financial liberalization reduce financing constraints?, Financial Management 32, 5-34.

Kose, M.A., E. Prasad, K. Rogoff, and S. Wei, 2006, Financial globalization: A reappraisal, working paper, IMF and Harvard University. NBER Working Paper No. 12484. 
La Porta, R., F. Lopez-de Silanes, and A. Shleifer, 1999, Corporate ownership around the world, Journal of Finance 54, 471-517.

La Porta, R., F. Lopez-de Silanes, A. Shleifer, and R.W. Vishny, 1997, Legal determinants of external finance, Journal of Finance 52, 1131-1155.

Laeven, L., 2003, Does financial liberalization reduce financing constraints?, Financial Management 32, 5-34.

Lemmon, M.L., and K.V. Lins, 2003, Ownership structure, corporate governance, and firm value: Evidence from the east asian financial crisis, Journal of Finance 58, 1445-1468.

Leuz, C., K.V. Lins, and F.E. Warnock, 2006, Do foreigners invest less in poorly governed firms?, nBER working paper \#12222, NBER, Cambridge, MA.

Lins, Karl, 2003, Equity ownership and firm value in emerging markets, Journal of Financial and Quantitative Analysis 38, 159-184.

Lins, Karl, and Henri Servaes, 2002, Is corporate diversification beneficial in emerging markets?, Financial Management 5, 5-31.

Lucas, R.E. Jr., 1990, Why doesn't capital flow from rich to poor countries?, American Economic Review 80, 92-96.

Mitton, Todd, 2002, A cross-firm analysis of the impact of corporate governance on the east asian financial crisis, Journal of Financial Economics 64, 215-241.

Mitton, Todd, 2006, Stock market liberalization and operating performance at the firm level, Journal of Financial Economics 81, 625-647.

Shleifer, A., and D. Wolfenzon, 2002, Investor protection and equity markets, Journal of Financial Economics 66, 3-27.

Slovin, M.B., and M.E. Sushka, 1997, The implications of equity issuance decisions within a parent-subsidiary governance structure, Journal of Finance 52, 841-857.

Stulz, R.M., 2005, The limits of financial globalization, Journal of Finance 60, 1595-1638. 


\section{Table 1: Summary statistics}

This table presents summary statistics for a sample of 300 Korean firms around the equity market liberalization in January 1992. Sales growth is the growth in real sales. Investment is the ratio of capital expenditure to lagged assets. Inv $\Delta W C$ is the sum of capital expenditure and working capital investments divided by lagged assets. External finance is the total external finance divided by assets. Net debt issues and Net equity issues are ratios of net debt issuance and net equity issuance to assets, respectively. Market capitalization is the product of stock price times shares outstanding, in billions of won. Cash flow is the ratio of operating cash flow to assets. Leverage is the ratio of total debt to book assets. Tangibility is the ratio of fixed assets to total assets. The Dividend-paying firm indicator takes a value of one if the firm pays dividends, it is otherwise zero. Chaebol-af filiated indicator takes a value of one if the firm is affiliated with one of the 30 largest chaebols. Ownership-largest shareholder is the ownership of the largest shareholder. The $C A R$ is the mean-adjusted abnormal return in month 0 (the liberalization month defined as January 1992). It is estimated as the difference between returns for each firm in the liberalization month and the average pre-liberalization monthly return over the previous year ending 12 months before the liberalization date. DIFCOV is the difference between the historical covariance of the individual firm's stock return with the local market and its covariance with the world stock market index in the year before the liberalization. Turnover is the average turnover of the firm's shares in the 12-month period that starts 12 months before the liberalization.

\begin{tabular}{|c|c|c|c|c|c|c|}
\hline & \multirow[b]{2}{*}{$N$} & \multirow[b]{2}{*}{ Mean } & \multirow[b]{2}{*}{$S D$} & \multicolumn{3}{|c|}{ Distribution } \\
\hline & & & & $10^{t h}$ & $50^{t h}$ & $90^{t h}$ \\
\hline \multicolumn{7}{|c|}{ A. Firm and ownership characteristics in 1991} \\
\hline Sales growth & 300 & 0.087 & 0.198 & -0.078 & 0.055 & 0.300 \\
\hline Investment & 300 & 0.086 & 0.068 & 0.016 & 0.071 & 0.187 \\
\hline $\operatorname{Inv} \Delta W C$ & 300 & 0.080 & 0.087 & -0.029 & 0.079 & 0.192 \\
\hline External finance & 300 & 0.110 & 0.087 & 0.005 & 0.096 & 0.231 \\
\hline Net debt issues & 300 & 0.100 & 0.083 & 0.003 & 0.090 & 0.210 \\
\hline Net equity issues & 300 & 0.010 & 0.026 & 0.000 & 0.000 & 0.039 \\
\hline Market capitalization (b. won) & 300 & 86.901 & 186.017 & 7.125 & 29.066 & 193.122 \\
\hline Cash flow & 300 & 0.059 & 0.057 & 0.007 & 0.060 & 0.119 \\
\hline Leverage & 300 & 0.429 & 0.178 & 0.179 & 0.449 & 0.623 \\
\hline Tangibility & 300 & 0.321 & 0.159 & 0.112 & 0.313 & 0.530 \\
\hline Dividendpayingfirm & 300 & 0.820 & 0.385 & 0.000 & 1.000 & 1.000 \\
\hline Chaebol-affiliated & 300 & 0.290 & 0.455 & 0.000 & 0.000 & 1.000 \\
\hline Ownership - largest shareholder & 300 & 0.229 & 0.121 & 0.065 & 0.229 & 0.380 \\
\hline \multicolumn{7}{|c|}{ B. CARs, difference in covariance, and turnover } \\
\hline$C A R$ & 300 & 0.239 & 0.203 & 0.005 & 0.208 & 0.538 \\
\hline$D I F C O V(\times 100)$ & 300 & 0.284 & 0.105 & 0.135 & 0.299 & 0.406 \\
\hline Turnover $(\times 100)$ & 279 & 0.238 & 0.264 & 0.033 & 0.135 & 0.572 \\
\hline
\end{tabular}




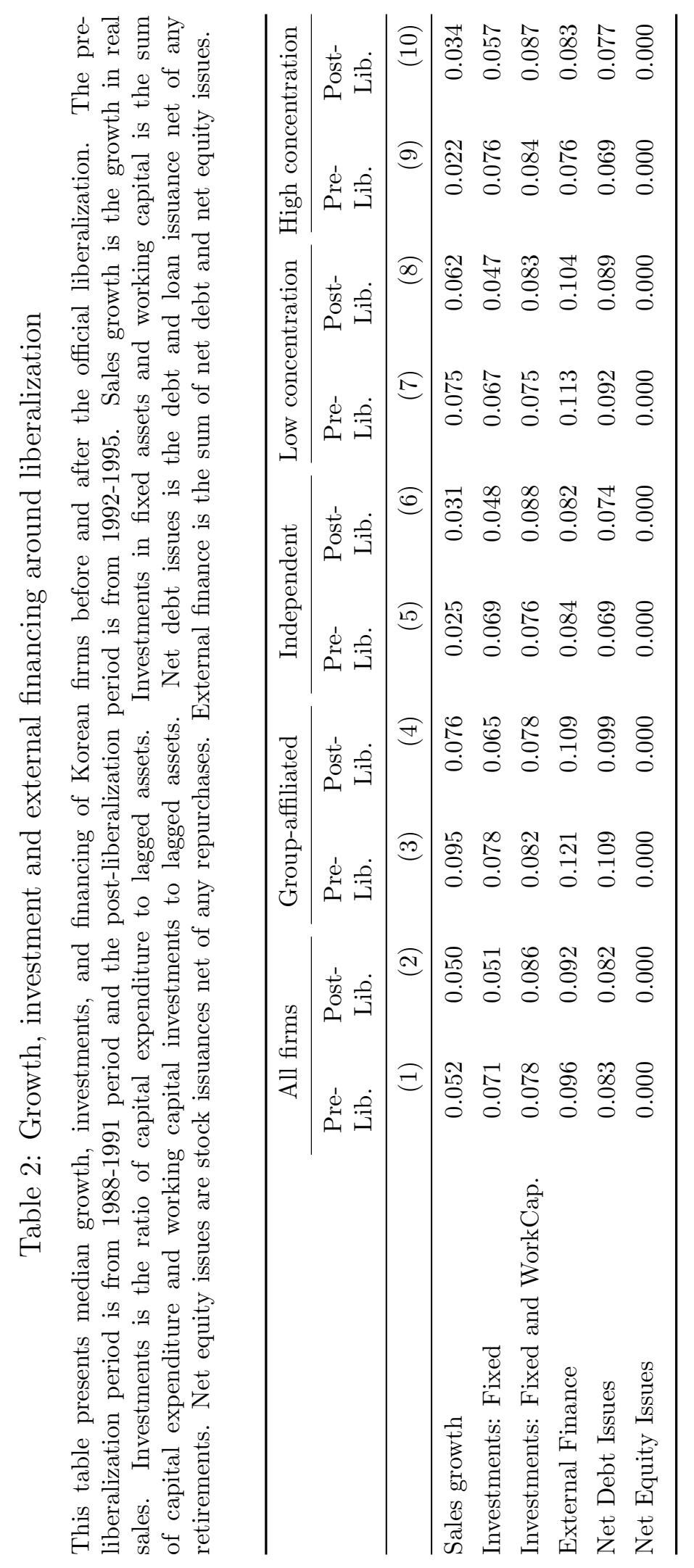




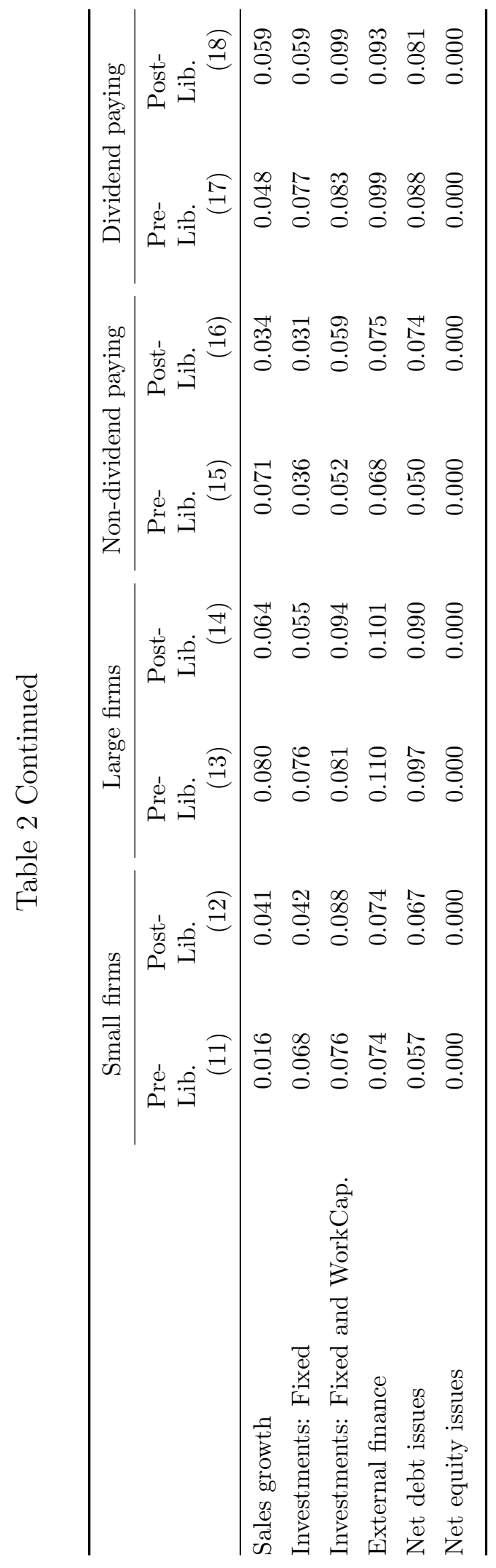


Table 3: Sales growth

This table reports coefficient estimates from regressions relating sales growth to lagged values of the natural logarithm of assets, dividend dummy, tangibility, independent firm indicator, concentrated ownership indicators, liberalization indicator, and various interactions terms between liberalization indicator and firm and ownership characteristics. Numbers in parentheses are t-statistics corrected for clustering at the firm level. ${ }^{a}$ Significant at the 1 percent level. ${ }^{b}$ Significant at the 5 percent level. ${ }^{c}$ Significant at the 10 percent level.

\begin{tabular}{|c|c|c|c|c|c|}
\hline & (1) & $(2)$ & $(3)$ & (4) & (5) \\
\hline $\log (\text { Assets })_{t-1}$ & $\begin{array}{c}0.034^{a} \\
(4.5)\end{array}$ & $\begin{array}{c}0.026^{a} \\
(6.0)\end{array}$ & $\begin{array}{c}0.027^{a} \\
(6.1)\end{array}$ & $\begin{array}{c}0.027^{a} \\
(6.1)\end{array}$ & $\begin{array}{c}0.027^{a} \\
(6.1)\end{array}$ \\
\hline Dividend Dummyt-1 & $\begin{array}{c}-0.014 \\
(-1.1)\end{array}$ & $\begin{array}{c}-0.058^{b} \\
(-2.1)\end{array}$ & $\begin{array}{c}-0.016 \\
(-1.2)\end{array}$ & $\begin{array}{c}-0.015 \\
(-1.2)\end{array}$ & $\begin{array}{c}-0.015 \\
(-1.1)\end{array}$ \\
\hline Tangibilityt $_{t-1}$ & $\begin{array}{c}-0.041 \\
(-1.2)\end{array}$ & $\begin{array}{c}-0.035 \\
(-1.0)\end{array}$ & $\begin{array}{c}-0.091^{c} \\
(-1.9)\end{array}$ & $\begin{array}{c}-0.041 \\
(-1.2)\end{array}$ & $\begin{array}{c}-0.044 \\
(-1.3)\end{array}$ \\
\hline Independentfirm & $\begin{array}{r}-0.007 \\
(-0.6)\end{array}$ & $\begin{array}{c}-0.009 \\
(-0.8)\end{array}$ & $\begin{array}{c}-0.007 \\
(-0.6)\end{array}$ & $\begin{array}{c}-0.033 \\
(-1.5)\end{array}$ & $\begin{array}{c}-0.008 \\
(-0.7)\end{array}$ \\
\hline Concentrated ownership & $\begin{array}{c}-0.020^{b} \\
(-2.2)\end{array}$ & $\begin{array}{c}-0.020^{b} \\
(-2.3)\end{array}$ & $\begin{array}{c}-0.020^{b} \\
(-2.3)\end{array}$ & $\begin{array}{c}-0.020^{b} \\
(-2.2)\end{array}$ & $\begin{array}{c}-0.046^{a} \\
(-2.8)\end{array}$ \\
\hline Liberalize & $\begin{array}{c}0.164 \\
(0.9)\end{array}$ & $\begin{array}{c}-0.070^{b} \\
(-2.2)\end{array}$ & $\begin{array}{c}-0.037^{b} \\
(-2.4)\end{array}$ & $\begin{array}{c}-0.048^{b} \\
(-2.3)\end{array}$ & $\begin{array}{c}-0.040^{a} \\
(-2.7)\end{array}$ \\
\hline Liberalize $\times$ Firm size & $\begin{array}{c}-0.010 \\
(-1.0)\end{array}$ & & & & \\
\hline Liberalize $\times$ Dividend dummy & & $\begin{array}{c}0.061^{c} \\
(1.8)\end{array}$ & & & \\
\hline Liberalize $\times$ Tangibility & & & $\begin{array}{c}0.033^{c} \\
(1.9)\end{array}$ & & \\
\hline Liberalize $\times$ Independent firm & & & & $\begin{array}{c}0.038 \\
(1.6)\end{array}$ & \\
\hline Liberalize $\times$ Concentrated owner ship & & & & & $\begin{array}{c}0.039^{c} \\
(1.8)\end{array}$ \\
\hline Constant & $\begin{array}{c}-0.515^{a} \\
(-3.6)\end{array}$ & $\begin{array}{c}-0.343^{a} \\
(-3.6)\end{array}$ & $\begin{array}{c}-0.374^{a} \\
(-4.0)\end{array}$ & $\begin{array}{c}-0.374^{a} \\
(-4.0)\end{array}$ & $\begin{array}{c}-0.377^{a} \\
(-4.1)\end{array}$ \\
\hline$\overline{R^{2}-\text { Adjusted }}$ & 0.040 & 0.042 & 0.042 & 0.041 & 0.041 \\
\hline Observations & 1773 & 1773 & 1773 & 1773 & 1773 \\
\hline
\end{tabular}




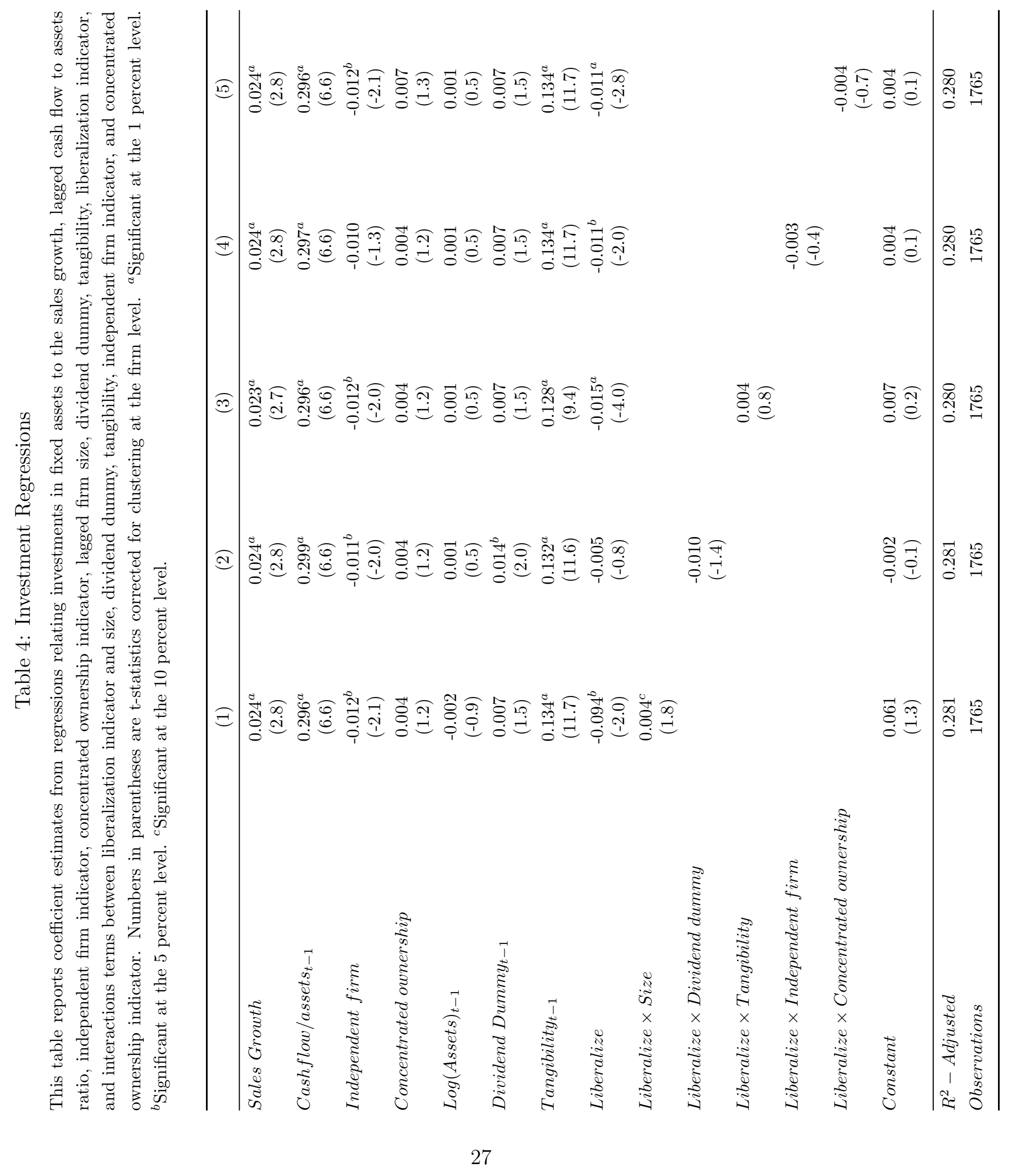


Table 5: External Financing, Chaebol and Ownership

This table reports coefficient estimates from fixed effects regressions relating financing to the natural logarithm of assets, profitability, liberalization indicator, and interactions terms between liberalization indicator and dividend paying, liberalization and independent firms, and liberalization and concentrated ownership. Numbers in parentheses are t-statistics corrected for clustering at the firm level. ${ }^{a}$ Significant at the 1 percent level. ${ }^{b}$ Significant at the 5 percent level. ${ }^{c}$ Significant at the 10 percent level.

\begin{tabular}{|c|c|c|c|c|c|}
\hline & (1) & $(2)$ & (3) & $(4)$ & (5) \\
\hline $\log (\text { Assets })_{t-1}$ & $\begin{array}{c}0.002 \\
(0.6)\end{array}$ & $\begin{array}{c}0.001 \\
(0.3)\end{array}$ & $\begin{array}{c}0.002 \\
(0.6)\end{array}$ & $\begin{array}{c}0.002 \\
(0.7)\end{array}$ & $\begin{array}{c}0.002 \\
(0.7)\end{array}$ \\
\hline Tangibility $_{t-1}$ & $\begin{array}{c}0.077^{a} \\
(3.9)\end{array}$ & $\begin{array}{c}0.076^{a} \\
(3.9)\end{array}$ & $\begin{array}{c}0.083^{a} \\
(3.7)\end{array}$ & $\begin{array}{c}0.078^{a} \\
(3.9)\end{array}$ & $\begin{array}{c}0.077^{a} \\
(3.9)\end{array}$ \\
\hline Profitability $_{t-1}$ & $\begin{array}{c}0.079 \\
(1.3)\end{array}$ & $\begin{array}{c}0.038 \\
(0.6)\end{array}$ & $\begin{array}{c}0.080 \\
(1.3)\end{array}$ & $\begin{array}{l}0.085 \\
(1.4)\end{array}$ & $\begin{array}{l}0.081 \\
(1.4)\end{array}$ \\
\hline Sales Growth $_{t-1}$ & $\begin{array}{c}0.010 \\
(0.9)\end{array}$ & $\begin{array}{c}0.010 \\
(0.9)\end{array}$ & $\begin{array}{c}0.010 \\
(0.9)\end{array}$ & $\begin{array}{c}0.008 \\
(0.8)\end{array}$ & $\begin{array}{c}0.009 \\
(0.8)\end{array}$ \\
\hline Leverage $_{t-1}$ & $\begin{array}{c}0.086^{a} \\
(4.0)\end{array}$ & $\begin{array}{c}0.096^{a} \\
(4.5)\end{array}$ & $\begin{array}{c}0.086^{a} \\
(4.0)\end{array}$ & $\begin{array}{c}0.086^{a} \\
(4.0)\end{array}$ & $\begin{array}{c}0.086^{a} \\
(4.0)\end{array}$ \\
\hline Independentfirm & $\begin{array}{c}-0.011 \\
(-1.1)\end{array}$ & $\begin{array}{c}-0.012 \\
(-1.2)\end{array}$ & $\begin{array}{c}-0.011 \\
(-1.1)\end{array}$ & $\begin{array}{c}-0.022^{c} \\
(-1.7)\end{array}$ & $\begin{array}{c}-0.011 \\
(-1.1)\end{array}$ \\
\hline Concentrated owner ship & $\begin{array}{c}-0.013^{b} \\
(-2.0)\end{array}$ & $\begin{array}{c}-0.013^{b} \\
(-2.0)\end{array}$ & $\begin{array}{c}-0.013^{b} \\
(-2.0)\end{array}$ & $\begin{array}{c}-0.013^{b} \\
(-2.0)\end{array}$ & $\begin{array}{c}-0.019^{b} \\
(-2.4)\end{array}$ \\
\hline Liberalize & $\begin{array}{c}-0.000 \\
(-0.0)\end{array}$ & $\begin{array}{c}-0.026^{a} \\
(-4.0)\end{array}$ & $\begin{array}{c}-0.009^{c} \\
(-1.8)\end{array}$ & $\begin{array}{c}-0.022^{a} \\
(-3.4)\end{array}$ & $\begin{array}{c}-0.016^{a} \\
(-3.2)\end{array}$ \\
\hline Liberalize $\times$ Size & $\begin{array}{c}-0.001 \\
(-0.2)\end{array}$ & & & & \\
\hline Liberalize $\times$ Dividend dummy & & $\begin{array}{c}0.020^{a} \\
(2.9)\end{array}$ & & & \\
\hline Liberalize $\times$ Tangibility & & & $\begin{array}{c}-0.004 \\
(-0.6)\end{array}$ & & \\
\hline Liberalize $\times$ Independent firm & & & & $\begin{array}{c}0.016^{b} \\
(2.1)\end{array}$ & \\
\hline Liberalize $\times$ Concentrated owner ship & & & & & $\begin{array}{c}0.010 \\
(1.4)\end{array}$ \\
\hline Constant & $\begin{array}{c}0.009 \\
(0.1)\end{array}$ & $\begin{array}{c}0.035 \\
(0.5)\end{array}$ & $\begin{array}{c}0.014 \\
(0.2)\end{array}$ & $\begin{array}{c}0.022 \\
(0.3)\end{array}$ & $\begin{array}{c}0.019 \\
(0.3)\end{array}$ \\
\hline$\overline{R^{2}-\text { Adjusted }}$ & 0.076 & 0.082 & 0.077 & 0.078 & 0.077 \\
\hline Observations & 1760 & 1760 & 1760 & 1760 & 1760 \\
\hline
\end{tabular}




\section{Table 6: Net Debt Financing}

This table reports coefficient estimates from fixed effects regressions relating external financing and net debt and equity issues to the natural logarithm of assets, profitability, sales growth, leverage, liberalization indicator, and interactions terms between liberalization and dividend, liberalization and liberalization and low leverage. Numbers in parentheses are t-statistics corrected for clustering at the firm level. ${ }^{a}$ Significant at the 1 percent level. ${ }^{b}$ Significant at the 5 percent level. ${ }^{c}$ Significant at the 10 percent level.

\begin{tabular}{|c|c|c|c|c|c|}
\hline & $(1)$ & $(2)$ & $(3)$ & $(4)$ & $(5)$ \\
\hline $\log (\text { Assets })_{t-1}$ & $\begin{array}{c}0.005 \\
(1.3)\end{array}$ & $\begin{array}{c}0.003 \\
(1.0)\end{array}$ & $\begin{array}{c}0.003 \\
(1.1)\end{array}$ & $\begin{array}{c}0.003 \\
(1.1)\end{array}$ & $\begin{array}{c}0.003 \\
(1.1)\end{array}$ \\
\hline Tangibility $_{t-1}$ & $\begin{array}{c}0.086^{a} \\
(4.7)\end{array}$ & $\begin{array}{c}0.086^{a} \\
(4.6)\end{array}$ & $\begin{array}{c}0.091^{a} \\
(4.4)\end{array}$ & $\begin{array}{c}0.086^{a} \\
(4.7)\end{array}$ & $\begin{array}{r}0.086^{a} \\
(4.6)\end{array}$ \\
\hline Profitability $_{t-1}$ & $\begin{array}{c}0.073 \\
(1.3)\end{array}$ & $\begin{array}{l}0.055 \\
(1.0)\end{array}$ & $\begin{array}{l}0.072 \\
(1.3)\end{array}$ & $\begin{array}{c}0.077 \\
(1.4)\end{array}$ & $\begin{array}{c}0.073 \\
(1.3)\end{array}$ \\
\hline Sales Growtht-1 & $\begin{array}{c}0.008 \\
(0.7)\end{array}$ & $\begin{array}{c}0.008 \\
(0.7)\end{array}$ & $\begin{array}{c}0.008 \\
(0.7)\end{array}$ & $\begin{array}{c}0.007 \\
(0.6)\end{array}$ & $\begin{array}{c}0.008 \\
(0.7)\end{array}$ \\
\hline Leverage $_{t-1}$ & $\begin{array}{c}0.088^{a} \\
(4.5)\end{array}$ & $\begin{array}{c}0.092^{a} \\
(4.6)\end{array}$ & $\begin{array}{c}0.088^{a} \\
(4.5)\end{array}$ & $\begin{array}{c}0.088^{a} \\
(4.5)\end{array}$ & $\begin{array}{r}0.088^{a} \\
(4.5)\end{array}$ \\
\hline Independentfirm & $\begin{array}{c}-0.009 \\
(-0.9)\end{array}$ & $\begin{array}{c}-0.009 \\
(-0.9)\end{array}$ & $\begin{array}{c}-0.009 \\
(-0.9)\end{array}$ & $\begin{array}{c}-0.019 \\
(-1.6)\end{array}$ & $\begin{array}{r}-0.009 \\
(-0.9)\end{array}$ \\
\hline Concentrated ownership & $\begin{array}{c}-0.005 \\
(-0.9)\end{array}$ & $\begin{array}{c}-0.005 \\
(-0.9)\end{array}$ & $\begin{array}{c}-0.005 \\
(-0.9)\end{array}$ & $\begin{array}{c}-0.005 \\
(-0.9)\end{array}$ & $\begin{array}{r}-0.010 \\
(-1.3)\end{array}$ \\
\hline Liberalize & $\begin{array}{c}0.030 \\
(0.6)\end{array}$ & $\begin{array}{c}-0.016^{b} \\
(-2.6)\end{array}$ & $\begin{array}{c}-0.008^{c} \\
(-1.9)\end{array}$ & $\begin{array}{c}-0.021^{a} \\
(-3.6)\end{array}$ & $\begin{array}{r}-0.014^{a} \\
(-3.2)\end{array}$ \\
\hline Liberalize $\times$ Size & $\begin{array}{c}-0.002 \\
(-0.9)\end{array}$ & & & & \\
\hline Liberalize $\times$ Dividend dummy & & $\begin{array}{l}0.008 \\
(1.2)\end{array}$ & & & \\
\hline Liberalize $\times$ Tangibility & & & $\begin{array}{c}-0.003 \\
(-0.6)\end{array}$ & & \\
\hline Liberalize $\times$ Independent firm & & & & $\begin{array}{c}0.016^{b} \\
(2.2)\end{array}$ & \\
\hline Liberalize $\times$ Concentrated ownership & & & & & $\begin{array}{c}0.007 \\
(1.1)\end{array}$ \\
\hline Constant & $\begin{array}{c}-0.056 \\
(-0.8)\end{array}$ & $\begin{array}{c}-0.021 \\
(-0.3)\end{array}$ & $\begin{array}{c}-0.030 \\
(-0.5)\end{array}$ & $\begin{array}{c}-0.023 \\
(-0.4)\end{array}$ & $\begin{array}{r}-0.027 \\
(-0.4)\end{array}$ \\
\hline$R^{2}-$ Adjusted & 0.089 & 0.090 & 0.089 & 0.091 & 0.090 \\
\hline Observations & 1760 & 1760 & 1760 & 1760 & 1760 \\
\hline
\end{tabular}




\section{Table 7: Net Equity Financing}

This table reports coefficient estimates from fixed effects regressions relating net equity financing to the natural logarithm of assets, profitability, sales growth, leverage, liberalization indicator, and interactions terms between liberalization and dividend, liberalization and liberalization and low leverage. Numbers in parentheses are t-statistics corrected for clustering at the firm level. ${ }^{a}$ Significant at the 1 percent level. ${ }^{b}$ Significant at the 5 percent level. ${ }^{c}$ Significant at the 10 percent level.

\begin{tabular}{|c|c|c|c|c|c|}
\hline & (1) & $(2)$ & (3) & $(4)$ & $(5)$ \\
\hline$\overline{\log (\text { Assets })_{t-1}}$ & $\begin{array}{c}-0.002 \\
(-1.5)\end{array}$ & $\begin{array}{c}-0.002^{b} \\
(-2.1)\end{array}$ & $\begin{array}{l}-0.001 \\
(-1.5)\end{array}$ & $\begin{array}{r}-0.001 \\
(-1.5)\end{array}$ & $\begin{array}{c}-0.001 \\
(-1.5)\end{array}$ \\
\hline Tangibility $_{t-1}$ & $\begin{array}{c}-0.009^{b} \\
(-2.0)\end{array}$ & $\begin{array}{c}-0.009^{b} \\
(-2.1)\end{array}$ & $\begin{array}{c}-0.008 \\
(-1.5)\end{array}$ & $\begin{array}{c}-0.009^{c} \\
(-1.9)\end{array}$ & $\begin{array}{c}-0.009^{b} \\
(-2.0)\end{array}$ \\
\hline Profitability $_{t-1}$ & $\begin{array}{c}0.006 \\
(0.3)\end{array}$ & $\begin{array}{l}-0.017 \\
(-0.9)\end{array}$ & $\begin{array}{l}0.008 \\
(0.4)\end{array}$ & $\begin{array}{c}0.008 \\
(0.4)\end{array}$ & $\begin{array}{l}0.009 \\
(0.5)\end{array}$ \\
\hline Sales Growth $h_{t-1}$ & $\begin{array}{c}0.002 \\
(0.6)\end{array}$ & $\begin{array}{l}0.002 \\
(0.6)\end{array}$ & $\begin{array}{l}0.002 \\
(0.5)\end{array}$ & $\begin{array}{c}0.002 \\
(0.5)\end{array}$ & $\begin{array}{c}0.002 \\
(0.5)\end{array}$ \\
\hline Leverage $_{t-1}$ & $\begin{array}{l}-0.002 \\
(-0.5)\end{array}$ & $\begin{array}{c}0.004 \\
(0.8)\end{array}$ & $\begin{array}{c}-0.002 \\
(-0.5)\end{array}$ & $\begin{array}{c}-0.002 \\
(-0.5)\end{array}$ & $\begin{array}{c}-0.002 \\
(-0.5)\end{array}$ \\
\hline Independentfirm & $\begin{array}{c}-0.002 \\
(-1.0)\end{array}$ & $\begin{array}{c}-0.003 \\
(-1.3)\end{array}$ & $\begin{array}{c}-0.002 \\
(-1.0)\end{array}$ & $\begin{array}{c}-0.002 \\
(-0.8)\end{array}$ & $\begin{array}{c}-0.002 \\
(-1.0)\end{array}$ \\
\hline Concentrated ownership & $\begin{array}{c}-0.007^{a} \\
(-4.1)\end{array}$ & $\begin{array}{c}-0.007^{a} \\
(-4.1)\end{array}$ & $\begin{array}{c}-0.007^{a} \\
(-4.1)\end{array}$ & $\begin{array}{c}-0.007^{a} \\
(-4.1)\end{array}$ & $\begin{array}{c}-0.009^{a} \\
(-3.4)\end{array}$ \\
\hline Liberalize & $\begin{array}{c}-0.030 \\
(-1.0)\end{array}$ & $\begin{array}{c}-0.010^{a} \\
(-4.6)\end{array}$ & $\begin{array}{l}-0.001 \\
(-0.3)\end{array}$ & $\begin{array}{c}-0.001 \\
(-0.4)\end{array}$ & $\begin{array}{c}-0.002 \\
(-1.0)\end{array}$ \\
\hline Liberalize $\times$ Size & $\begin{array}{c}0.002 \\
(1.0)\end{array}$ & & & & \\
\hline Liberalize $\times$ Dividend dummy & & $\begin{array}{c}0.012^{a} \\
(5.7)\end{array}$ & & & \\
\hline Liberalize $\times$ Tangibility & & & $\begin{array}{l}-0.000 \\
(-0.1)\end{array}$ & & \\
\hline Liberalize $\times$ Independent firm & & & & $\begin{array}{c}0.000 \\
(0.1)\end{array}$ & \\
\hline Liberalize $\times$ Concentrated owner ship & & & & & $\begin{array}{c}0.003 \\
(1.1)\end{array}$ \\
\hline Constant & $\begin{array}{c}0.065^{b} \\
(2.2)\end{array}$ & $\begin{array}{c}0.057^{a} \\
(3.1)\end{array}$ & $\begin{array}{c}0.044^{a} \\
(2.6)\end{array}$ & $\begin{array}{c}0.045^{a} \\
(2.6)\end{array}$ & $\begin{array}{c}0.046^{a} \\
(2.7)\end{array}$ \\
\hline$R^{2}-$ Adjusted & 0.018 & 0.035 & 0.017 & 0.017 & 0.018 \\
\hline Observations & 1760 & 1760 & 1760 & 1760 & 1760 \\
\hline
\end{tabular}


Table 8: Liberalization returns and corporate governance

This table reports coefficient estimates from OLS regressions relating cumulative abnormal returns in the liberalization month to difference in covariance (DIFCOV), chaebol indicator variable, share ownership of the largest owner, stock turnover, cash flow, leverage and firm size. $C A R$ is the mean adjusted abnormal return in month 0 estimated as the difference between return for each firm in the liberalization month and the average pre-liberalization monthly return over the previous year ending 12 months before the liberalization date. DIFCOV is the difference between the historical covariance of the individual firm's stock return with the local market and its covariance with the world stock market index in the year before the liberalization. Turnover is the average turnover of the firm's shares in the period which starts 24 months before the liberalization and ends 12 months before the liberalization. Leverage is the ratio of total debt to book assets. Cash flow is the ratio of operating cash flow to assets. Market capitalization is the product of stock price times shares outstanding and is reported in billions of Korean currency. Numbers in parentheses are robust standard errors. ${ }^{a}$ Significant at the 1 percent level. ${ }^{b}$ Significant at the 5 percent level. ${ }^{c}$ Significant at the 10 percent level.

\begin{tabular}{lcccc}
\hline & $(1)$ & $(2)$ & $(3)$ & $(4)$ \\
\hline DIFCOV $(\times 100)$ & $0.313^{b}$ & $0.335^{a}$ & $0.321^{b}$ & $0.340^{a}$ \\
& $(2.4)$ & $(2.6)$ & $(2.5)$ & $(2.7)$ \\
Independent firm & & $0.108^{a}$ & & $0.097^{a}$ \\
Concentrated Ownership & & $(3.6)$ & & $(3.1)$ \\
& & & $0.058^{b}$ & $0.046^{b}$ \\
Stock turnover $(\times 100)$ & $-0.099^{b}$ & $-0.118^{a}$ & $-0.078^{c}$ & $(2.0)$ \\
& $(-2.3)$ & $(-2.8)$ & $(-1.8)$ & $-0.099^{b}$ \\
Log $($ Market capitalization $)$ & $-0.043^{a}$ & $-0.023^{b}$ & $-0.037^{a}$ & $-0.021^{b}$ \\
& $(-5.5)$ & $(-2.4)$ & $(-4.8)$ & $(-2.2)$ \\
Leverage & -0.154 & -0.115 & -0.140 & -0.108 \\
& $(-1.6)$ & $(-1.2)$ & $(-1.5)$ & $(-1.2)$ \\
Cash flow & $0.910^{a}$ & $0.860^{a}$ & $0.883^{a}$ & $0.844^{a}$ \\
Constant & $(2.6)$ & $(2.7)$ & $(2.7)$ & $(2.8)$ \\
& $0.358^{a}$ & $0.195^{b}$ & $0.295^{a}$ & $0.161^{b}$ \\
\hline$R^{2}-$ Adjusted & $(5.6)$ & $(2.5)$ & $(4.6)$ & $(2.2)$ \\
Observations & 0.218 & 0.253 & 0.234 & 0.262 \\
\hline
\end{tabular}


Table 9: Liberalization returns and changes in firm performance

This table reports coefficient estimates from OLS regressions relating cumulative abnormal returns in the liberalization month to difference in covariance (DIFCOV), chaebol indicator variable, share ownership of the largest owner, stock turnover, cash flow, leverage and firm size. $C A R$ is the mean adjusted abnormal return in month 0 estimated as the difference between return for each firm in the liberalization month and the average pre-liberalization monthly return over the previous year ending 12 months before the liberalization date. DIFCOV is the difference between the historical covariance of the individual firm's stock return with the local market and its covariance with the world stock market index in the year before the liberalization. Turnover is the average turnover of the firm's shares in the period which starts 24 months before the liberalization and ends 12 months before the liberalization. Leverage is the ratio of total debt to book assets. Cash flow is the ratio of operating cash flow to assets. Market capitalization is the product of stock price times shares outstanding and is reported in billions of Korean currency. Numbers in parentheses are robust standard errors. ${ }^{a}$ Significant at the 1 percent level. ${ }^{b}$ Significant at the 5 percent level. ${ }^{c}$ Significant at the 10 percent level.

\begin{tabular}{|c|c|c|c|c|c|}
\hline & (1) & $(2)$ & (3) & $(4)$ & (5) \\
\hline$D I F C O V(\times 100)$ & $\begin{array}{c}0.321^{b} \\
(2.5)\end{array}$ & $\begin{array}{c}0.375^{a} \\
(3.0)\end{array}$ & $\begin{array}{c}0.339^{a} \\
(2.7)\end{array}$ & $\begin{array}{c}0.327^{b} \\
(2.1)\end{array}$ & $\begin{array}{c}0.323^{b} \\
(2.1)\end{array}$ \\
\hline Independent firm & $\begin{array}{c}0.095^{a} \\
(3.0)\end{array}$ & $\begin{array}{c}0.092^{a} \\
(2.9)\end{array}$ & $\begin{array}{c}0.097^{a} \\
(3.1)\end{array}$ & $\begin{array}{c}0.082^{b} \\
(2.4)\end{array}$ & $\begin{array}{c}0.080^{b} \\
(2.3)\end{array}$ \\
\hline Concentrated Ownership & $\begin{array}{c}0.044^{c} \\
(1.9)\end{array}$ & $\begin{array}{c}0.047^{b} \\
(2.0)\end{array}$ & $\begin{array}{c}0.045^{c} \\
(2.0)\end{array}$ & $\begin{array}{c}0.049^{c} \\
(1.7)\end{array}$ & $\begin{array}{c}0.048^{c} \\
(1.7)\end{array}$ \\
\hline Stock turnover $(\times 100)$ & $\begin{array}{c}-0.098^{b} \\
(-2.3)\end{array}$ & $\begin{array}{c}-0.099^{b} \\
(-2.2)\end{array}$ & $\begin{array}{c}-0.100^{b} \\
(-2.3)\end{array}$ & $\begin{array}{r}-0.047 \\
(-0.8)\end{array}$ & $\begin{array}{c}-0.048 \\
(-0.8)\end{array}$ \\
\hline$\Delta$ Sales Growth & $\begin{array}{l}0.052 \\
(0.9)\end{array}$ & & & & \\
\hline$\Delta$ Investment & & $\begin{array}{c}0.353^{b} \\
(2.4)\end{array}$ & & & \\
\hline$\Delta$ External Finance & & & $\begin{array}{l}0.125 \\
(0.7)\end{array}$ & $\begin{array}{c}0.631^{b} \\
(2.1)\end{array}$ & \\
\hline$\Delta$ External Finance $\times$ Large & & & & $\begin{array}{r}-0.935^{b} \\
(-2.4)\end{array}$ & \\
\hline$\Delta N e t$ Debt Issue & & & & & $\begin{array}{c}0.656^{c} \\
(1.8)\end{array}$ \\
\hline$\Delta N e t$ Equity Issue & & & & & $\begin{array}{c}0.588 \\
(1.0)\end{array}$ \\
\hline$\Delta$ Net debt issue $\times$ Large & & & & & $\begin{array}{r}-0.848^{c} \\
(-1.9)\end{array}$ \\
\hline$\Delta N$ et equity issue $\times$ Large & & & & & $\begin{array}{c}-1.390 \\
(-1.5)\end{array}$ \\
\hline
\end{tabular}


Table 9 Continued.

\begin{tabular}{lccccc}
\hline & $(1)$ & $(2)$ & $(3)$ & $(4)$ & $(5)$ \\
\hline Log(Market capitalization $)$ & $-0.021^{b}$ & $-0.022^{b}$ & $-0.020^{b}$ & $-0.018^{c}$ & $-0.018^{c}$ \\
& $(-2.2)$ & $(-2.3)$ & $(-2.1)$ & $(-1.8)$ & $(-1.9)$ \\
Leverage & -0.103 & -0.109 & -0.104 & $-0.208^{b}$ & $-0.204^{b}$ \\
& $(-1.1)$ & $(-1.2)$ & $(-1.2)$ & $(-2.3)$ & $(-2.2)$ \\
Cash flow & $0.850^{a}$ & $0.949^{a}$ & $0.827^{a}$ & $0.557^{a}$ & $0.561^{a}$ \\
& $(2.9)$ & $(3.9)$ & $(2.8)$ & $(2.8)$ & $(2.8)$ \\
Constant & $0.170^{b}$ & $0.155^{b}$ & $0.161^{b}$ & $0.193^{b}$ & $0.196^{b}$ \\
& $(2.3)$ & $(2.2)$ & $(2.2)$ & $(2.6)$ & $(2.6)$ \\
\hline$R^{2}-$ Adjusted & 0.261 & 0.278 & 0.261 & 0.325 & 0.318 \\
Observations & 279 & 279 & 279 & 183 & 183 \\
\hline
\end{tabular}

